\title{
POLÍTICA FLORESTAL PRODUTIVA E A ESTRUTURA ADMINISTRATIVA DE INCLUSÃO DAS PEQUENAS PROPRIEDADES RURAIS NA CADEIA PRODUTIVA DA MADEIRA PARANAENSE
}

\author{
José Tarciso Fialho $^{1}$, Antonio Rioyei Higa ${ }^{2}$, Anadalvo Juazeiro dos Santos ${ }^{3}$, Jorge Roberto Malinovski $^{2}$ \\ ${ }^{1}$ Eng. Agrônomo, Dr., EMATER, Curitiba, PR, Brasil - tarcisofialho@yahoo.com.br \\ ${ }^{2}$ Eng. Florestal, Dr., Depto. de Ciências Florestais da UFPR, Curitiba, PR, Brasil - higa@ufpr.br; malinoviski@ufpr.br \\ ${ }^{3}$ Eng. Florestal, Dr., Depto. de Economia Rural e Extensão, UFPR, Curitiba, PR, Brasil - ajsantos@ufpr.br \\ Recebido para publicação: 12/12/2007 - Aceito para publicação: 31/03/2010
}

\begin{abstract}
Resumo
Este artigo discorre a respeito da estrutura administrativa relacionada à condução da política florestal produtiva do estado do Paraná, bem como das diretrizes que devem ser estabelecidas para a inclusão das pequenas propriedades rurais na cadeia produtiva da madeira. Buscou-se retratar a percepção dos diversos agentes que atuam ao longo da cadeia produtiva da madeira no estado do Paraná. Trata-se de uma pesquisa descritiva baseada em dados coletados de fontes bibliográficas, assim como dos questionários aplicados aos grupos selecionados. Assim, foram considerados três grupos: a) grupo Governo (GOV), composto por 81 questionários; b) grupo não-governo (N-GOV), composto por 76 questionários; e c) grupo produtores (PROD), composto por 97 questionários. Os resultados demonstram que os grupos pesquisados consideram que a estrutura de governo que trata do segmento florestal apresenta uma característica voltada mais para as questões ambientais e ecológicas do que do ponto de vista produtivo, onde se encontram os aspectos econômicos e sociais.

Palavras-chave: Estrutura administrativa; pequenas propriedades rurais; política florestal produtiva; cadeia produtiva da madeira.
\end{abstract}

\begin{abstract}
Productive forest policy and administrative structure of inclusion of small rural properties of wood supply chain of the Parana State. This article aims at describing the administrative structure associated to the performance of the productive forestry policies of the State of Parana, as well as the guidelines which should be established for the small farms inclusion in the wood production chain. This was one of the objectives of a doctorate thesis presented in the Forestry Engineering Program at the Federal University o Parana, with minor in Silviculture, and within the research lines of production, provision, protection, and forestry reestablishment. This work reflects a descriptive research based on data collected from the literature, as well as from an inquiry form applied to selected groups. Three groups were, then, considered to know: a) a government group (GOV), with 81 forms; b) a non-government group (N-GOV), with 76 forms; and c) a farms group (PROD), with 97 forms, adding to 254 inquiry forms. The results showed that, under the viewpoint of the interviewed personnel, the government structure is more devoted to ecological-environmental questions than to production itself, where the economical and social aspects are found.

Keywords: Administrative structure; small farms; productive forestry policy; wood production chain.
\end{abstract}

\section{INTRODUÇÃO}

Ao longo das últimas décadas, as pequenas propriedades rurais paranaenses não vêm recebendo dos governos a atenção necessária para que possam se integrar de forma eficiente na cadeia produtiva da madeira. Isso pode ser evidenciado pela FAO (2004), ao afirmar que há dificuldades desses proprietários em se integrar ao processo produtivo, principalmente com as empresas do setor, destacando-se o excesso de burocracia dos órgãos para o licenciamento de corte, a deficiência da assistência técnica florestal, a 
tradição extrativista do produtor rural em relação às florestas, o longo prazo para o retorno do investimento e a legislação ambiental restritiva.

O setor florestal produtivo paranaense, por ser considerado autossuficiente em termos econômicos, ao longo das últimas décadas não vem recebendo dos governos a atenção necessária para o desenvolvimento de uma política consistente sobre a ampliação da base produtiva florestal do estado. Assim, coube ao próprio setor organizado, constituído principalmente pelas empresas florestais, implementar suas próprias estratégias, tendo constituído, ao longo desse período, um complexo industrial dos mais modernos do país.

Segundo dados da Associação Paranaense de Empresas de Base Florestal (APRE/PR - 2005), o setor florestal, mesmo explorando apenas cerca de $3 \%$ da área territorial do estado, já responde pelo $2^{\circ}$ lugar entre os exportadores do agronegócio paranaense e é o $3^{\circ}$ na pauta de exportação estadual, perdendo apenas para o segmento de grãos e para o setor automobilístico. Isso caracteriza a grande capacidade tecnológica do setor florestal como uma atividade de altíssima capacidade de agregação de valor.

De acordo com a Embrapa (2005), o estado do Paraná apresenta um real potencial climático adequado para a produção de madeira (maior área plantada de pinus do Brasil, com uma extensão de plantios florestais correspondente a 33\% de toda área cultivada no país), conseguindo manter um nível tecnológico silvicultural compatível com os mais modernos do mundo. Dispõe também de capacidade competitiva dentro dos parâmetros da sustentabilidade, além de possuir agricultores competentes e um conjunto apropriado para a inserção desses agricultores no processo produtivo florestal, ou seja, atributos capazes de gerar renda, emprego e melhoria da qualidade de vida dos produtores e, consequentemente, reduzir o êxodo rural, amenizando a pressão social nos grandes e médios centros urbanos.

Entretanto, em que pese o sucesso do setor empresarial florestal, os reflexos negativos da quase ausência de uma política florestal produtiva de forma efetiva recaíram sobre os silvicultores, notadamente os pequenos produtores rurais (PPRs) que, por falta de apoio institucional, não conseguiram se integrar de forma eficiente à cadeia produtiva da madeira (CPM). Assim, embora, ao longo dessa cadeia, possam se observar ganhos econômicos consideráveis, em função do potencial agregador da transformação madeireira, os agricultores, que compõem a base produtiva da floresta, não vêm conseguindo aumentar a sua participação de forma significativa, mantendo-se sempre à margem do processo. Um dos problemas relativos a isso encontra-se associado às diretrizes governamentais direcionadas ao apoio à ampliação da base florestal do estado, em que se verifica a ausência de um foro adequado para que o setor produtivo possa discutir suas questões.

Para tanto, questiona-se: na percepção dos atores sociais que compõem a CPM, as diretrizes da política florestal implementada pelo governo são adequadas, em termos de estrutura administrativa, objetivos programáticos, pesquisa e assistência técnica, necessárias para a efetiva inclusão das PPRs na CPM?

Definiu-se como hipótese: se o modelo administrativo e gerencial da política florestal produtiva paranaense se transferisse das estruturas da Secretaria do Meio Ambiente e dos Recursos Hídricos (SEMA) para as da Secretaria da Agricultura e do Abastecimento (SEAB), poderia se adequar melhor ao processo burocrático, facilitando a inclusão das pequenas propriedades rurais na cadeia produtiva da madeira.

\section{REVISÃO BIBLIOGRÁFICA}

De acordo com as teorias de administração (CHIAVENATO, 1993), um conjunto de atividades ordenadas e estruturadas, orgânica e institucionalmente, compõe um projeto, assim como um conjunto de projetos constitui um programa que, somado a outros programas e a outras diretrizes, forma uma política de um determinado setor. Em especial, segundo Howard Gron ${ }^{1}$ (1947), citado por GRIPP, 2006, a política florestal é um conjunto de medidas que o Estado ou as coletividades locais podem tomar para salvaguarda do interesse geral na gestão e exploração das florestas. Já a FAO (1997) conceitua a política florestal como um quadro de princípios e objetivos (gerais e específicos) e normas, resultantes de processos interinstitucionais participativos de diálogo e consenso, que visam regular e orientar a proteção e conservação dos recursos florestais como parte de uma política de desenvolvimento sustentável (SILVA, 2006).

\footnotetext{
${ }^{1}$ GRON, A. H. The Economic Foundations of Forest Politics. Unasylva - Vol. 1, n.. 3. Food and Agriculture Organization of the United Nations. Disponível em: <http://www.fao.org/docrep/x5341e/x5341e00.htm〉.
} 
Segundo Santos (1994): “A política florestal constitui, em princípio, o conjunto de medidas legislativas e regulamentares tomadas pelas autoridades públicas para organizar a gestão das florestas e produtos florestais no país. Há necessidade de se implementar uma série de instrumentos políticoorganizacionais, entre os quais, destacam-se: criação de um conselho estadual de florestas; criação de uma lei florestal para o Paraná; instituição de um fundo de desenvolvimento florestal; readequação da estrutura administrativa do estado; criação de um sistema de informação florestal; instrumentos fiscais; instrumentos financeiros; Estado como agente indutor; iniciativa privada como agente executor.

Mas, segundo Krishnaswamy; Hanson (1999, apud AICHER, 2004): "Depois da Conferência no Rio, em 1992, muitas pessoas chegaram à conclusão de que as soluções e as respostas aos problemas da perda e da degradação das florestas se encontravam na área sociopolítica e não na tecnológica". Ressaltase que, em seu estudo sobre a política florestal europeia, Aicher (2004) levanta a questão do "incômodo" que a temática ambiental provocava nas políticas públicas, principalmente no período que antecedeu a integração europeia, configurando um processo transnacional em oposição ao processo internacional anterior. Segundo o autor, a política florestal tratava de uma perspectiva bastante funcionalista e reduzida a questões técnicas do setor florestal, considerando-se que, nesse setor, incluíam-se os proprietários das florestas, os usuários da madeira e a administração estatal.

O Ministério do Meio Ambiente (MMA) também ressalta a necessidade de mudança de enfoque nas políticas florestais, enfatizando que, "no final dos anos 70, mudanças nos conceitos de desenvolvimento econômico criaram uma situação nova para o uso dos recursos naturais" (BRASIL, 2005). Salienta que a Comissão de Desenvolvimento Sustentável (CDS) das Nações Unidas concluiu por uma abordagem holística das funções ambientais e de desenvolvimento das florestas. "Considerou também que ações adicionais eram necessárias para aperfeiçoar a conservação e o manejo sustentável das florestas existentes, para restaurar florestas/áreas degradadas e criar novas florestas. Essa medida incluiria plantações florestais, de modo a reduzir a pressão sobre as florestas naturais e aumentar a oferta de madeira" (BRASIL, 2005).

\section{Evolução da política florestal no Paraná}

De acordo com Tourinho (2005), em 1917, o Código Civil deu aos bens ambientais um tratamento sob a ótica dos interesses privados. Encontra-se também essa proteção no Decreto 4.421/21, que criou o Serviço Florestal do Brasil, com o propósito de conservar os recursos florestais daquela época (PIERANGELLI, 1980). Mas apenas em 1920 é que se tomou a iniciativa de se criar uma legislação apropriada, quando o então presidente Epitácio Pessoa formou uma subcomissão para elaborar um anteprojeto que daria origem ao Código Florestal. Ocorre, porém, que apenas em 1934 é que o projeto foi transformado no Decreto 23.793, que, na época, ficou conhecido como Código Florestal de 1934. Esse Decreto veio para regulamentar a utilização das florestas e classificar os atos danosos ao meio ambiente como contravenções penais. Nesse mesmo ano, promulgou-se também uma nova Constituição Federal, contendo alguns dispositivos de proteção ao meio ambiente. Naquela época surgem também o Código de Águas, o Decreto 24.643/34 e o Código de Caça, Decreto 24.645/34 (AHRENS, 2003). Na década de 1960, houve uma intensa elaboração legislativa na área ambiental, surgindo uma nova reformulação no que tange à tutela penal ambiental. Elaborou-se um novo Código Florestal, Lei 4.771/65 (alterado pela MP 2166-67/2001), uma Lei de proteção à fauna (Lei 5.197/67), um Decreto de proteção à pesca (Decreto-Lei 221/67) e outro Decreto para proteger os recursos hídricos (Decreto 50.877/61, depois complementado pelo Decreto-Lei 303/67) (WAINER, 1991, apud TOURINHO, 2005). Mas foi somente com a Lei 6.938/81 que se instituiu a Política Nacional de Meio Ambiente, que se tentou adequar às novas exigências e a uma nova visão da proteção ambiental, responsabilizando o autor dos atos danosos ao meio ambiente e este tendo como obrigação reparar o dano (AHRENS, 2003).

Em 1988 tem-se uma nova Constituição, que inovou em várias questões relativas ao meio ambiente. Instituiu um capítulo inteiro para a proteção ao meio ambiente (Título VIII, Capítulo VI), distribuindo responsabilidades aos estados, municípios e à União. Teve também a elaboração de várias outras leis específicas na área ambiental, que expressam as necessidades ao mundo moderno frente à evolução tecnológica, como a necessidade de proteção à camada de ozônio, a regulamentação do uso de agrotóxicos, a regulamentação das atividades nucleares frente aos sérios danos que podem causar, como o acidente ocorrido na usina de Chernobyl, na antiga União Soviética (FERREIRA, 1995, apud TOURINHO, 2005). Portanto a Constituição de 1988 buscou não só inserir a matéria relacionada com a 
preservação ambiental, mas também medidas coercivas no âmbito penal aos infratores das normas. Somado a isso, como reforço aos aspectos ambientais, encontra-se a Lei de Crimes Ambientais (Lei 9.605/98) que, em suas prescrições, além de tipificar penalmente inúmeras outras condutas como lesivas à natureza, adota princípios ramificados nas principais convenções mundiais sobre o meio ambiente, no encalço de sua preservação e na busca de um progresso economicamente sustentável. Porém é preciso cautela na sua aplicação, pois, desde que não se agrida realmente a natureza, devemos utilizar a madeira, o minério, a caça, a pesca e outros recursos naturais (SALES, 2006).

Mas quanto ao fomento florestal, há que se considerar que a própria legislação estabelece princípios para que os estados implementem a atividade florestal em bases produtivas. Assim, pode-se observar na Constituição Federal que o fomento florestal público é o "[...] mecanismo de desenvolvimento amplamente contemplado por diplomas legais que norteiam a atividade florestal no Brasil”"2.

\section{Modelo institucional da política florestal}

Tendo por base o chamado Pacto Federativo de Gestão Descentralizada, os argumentos para o desenvolvimento das políticas florestais ficaram a cargo dos estados. Vale ressalvar a Lei $\mathrm{n}^{\circ} 11.284$, de 2 de março de 2006, que dispõe sobre a gestão de florestas públicas para produção sustentável, instituindo o Serviço Florestal Brasileiro (SFB) na estrutura do MMA, e cria o Fundo Nacional de Desenvolvimento Florestal (FNDF). Pela forte influência internacional a respeito das pressões ambientais, também foram essas as premissas que passaram a orientar as prioridades das políticas estaduais. Isso leva ao questionamento das próprias estruturas administrativas e organizacionais do setor florestal que, no estado do Paraná, acabou por caracterizar a produção florestal como simples parte da gestão ambiental. "A política estadual do atual Governo para o manejo dos recursos naturais tem enfocado principalmente as atividades de cunho ambiental e social, ao invés da promoção de reflorestamentos de produção industrial" (IAP/SEMA apud FAO, 2004).

Assim, não se verificaram, nos últimos anos, políticas consistentes ou estímulos específicos para o desenvolvimento do setor florestal produtivo. Consequentemente, os investimentos foram reduzidos, limitados às iniciativas das empresas estruturadas e sem a participação da pequena produção dentro do processo produtivo. Além disso, o excesso burocrático, principalmente na fiscalização, passou a imperar, e isso, somado à falta de informação, acabou por levar desconfiança aos pequenos produtores, que se sentiam inseguros para um investimento de longo prazo, como os plantios florestais.

Vale ressaltar que o próprio governo assume que houve um "certo exagero" no tocante ao ambientalismo, principalmente após a RIO-92: O "ambientalismo" surgido nessa época, em função da ECO 92 e da facilidade de aplicação da legislação punitiva, levaram o IAP a uma excessiva concentração de ações na fiscalização, ficando o desenvolvimento florestal relegado a plano secundário (IAP, 2006). Por isso a política estadual para o manejo dos recursos naturais tem enfocado principalmente as atividades de cunho ambiental e social, ao invés da promoção de reflorestamentos de produção industrial (comunicação pessoal, IAP/SEMA, in: FAO, 2004). Em especial no que se refere à percepção dos pequenos agricultores quanto ao ambientalismo, algumas conclusões de Malinovski (2002) dão conta de que, do ponto de vista comportamental, se percebe que o produtor rural possui uma postura defensiva quando se trata de questões ligadas ao setor ambiental. Na ótica do produtor, o Estado criou uma política ambiental altamente restritiva ao pequeno proprietário rural, fazendo com que muitos deles vendam suas terras e se mudem para a cidade grande, ocasionando o êxodo rural. O produtor rural acredita que acabou assumindo de forma ditatorial o ônus dos problemas ambientais gerados no passado.

Por conta de todas essas pressões, o governo do Paraná também modificou a sua legislação. Assim, no Diário Oficial de 27 de julho de 1992, foi publicada a Lei 10.066, que criou a Secretaria de Estado do Meio Ambiente (SEMA), bem como a entidade autárquica Instituto Ambiental do Paraná (IAP). Em seu Artigo 14 consta: "Ficam extintos a Superintendência de Recursos Hídricos e Meio Ambiente (Surehma) e o Instituto de Terras, Cartografia e Florestas (ITCF)". Esses fatos conduzem a uma análise a respeito das diversas faces que envolvem a questão da produção florestal no estado, tendo por um lado o setor produtivo e, por outro, os aspectos legais aos quais o governo se dedicou nesse período de tempo. Como ressalta a FAO (2004), "no Paraná, a condução da política estadual de incentivos e de

\footnotetext{
${ }^{2}$ Também contido na Revista Ambiente Brasil (2006), como reforço a esse conceito.
} 
desenvolvimento florestal está a cargo de órgãos públicos ambientais, notadamente o Instituto Ambiental do Paraná, órgão da Secretaria de Meio Ambiente (SEMA)".

Vale ressaltar que entre os objetivos do IAP, instruídos no art. $6^{\circ}$ da referida lei, constam, além de fazer cumprir a legislação ambiental e conceder o licenciamento de atividades produtivas, outros objetivos: X - fiscalizar, orientar e controlar a recuperação de áreas degradadas por atividades econômicas de qualquer natureza; XI - promover, coordenar e executar a educação ambiental formal e não-formal (Lei $\mathrm{n}^{\circ}$ 10.066/92). Esses objetivos estão destacados apenas para reforçar a ideia de que o estado não deseja apenas fiscalizar, mas também orientar, apoiar e conscientizar os produtores de forma geral (e os cultivadores de florestas, em especial), para demonstrar que é possível implantar florestas, manejá-las e produzir dividendos sem, no entanto, comprometer os recursos naturais de forma irreversível. É dentro desse enfoque que a questão da fiscalização sobre os plantios florestais encontra-se inserida no estado do Paraná, contando com as estruturas do Instituto Ambiental do Paraná, da SEMA, e do Departamento de Fiscalização e Defesa Agropecuária, da SEAB, cujas atribuições recaem na fiscalização das leis ambientais envolvendo os solos e os agrotóxicos, bem como da produção de mudas através da fiscalização e registros de viveiros florestais.

O IAP, pela sua própria característica fiscalizatória, apresenta uma visão do setor produtivo florestal como uma atividade que deve receber atenção redobrada, uma vez que pode colocar em risco o meio ambiente, a partir do momento em que padroniza a flora com maciços de monoculturas que, quando em excesso, podem causar danos ambientais de grande monta. Além disso, a legislação federal que trata da Reserva Legal (RL), da Mata Ciliar (MC) e da Área de Preservação Permanente (APP) coloca o IAP em situação de "alerta permanente", uma vez que tem de fiscalizar o seu cumprimento em todas as instâncias, seja para pequenos, seja para médios ou grandes propriedades, além das empresas agrícolas.

Mas o IAP, por sua vez, também é "fiscalizado" pelo Ministério Público, que exige o cumprimento imediato da legislação. Entretanto, embora esteja o setor administrado sob a ótica ambiental, não significa que haja descaso quanto aos aspectos produtivistas da exploração florestal, tendo em vista que se busca a sustentabilidade da produção ao se garantir a adequação da legislação, bem como a harmonia entre o que se pode produzir e o que se deve preservar. Por outro lado, permanece o aspecto da necessidade de se cumprirem as leis, principalmente as federais, tendo em vista a dificuldade de negociação e a supervisão do Ministério Público, cuja atuação é bastante ativa no estado.

O SISLEG foi instituído no estado do Paraná através do Decreto Estadual 387/99, com base em legislações florestais federal e estadual. Esse sistema se integra aos principais mecanismos institucionais de estímulo à atividade e ao manejo florestal. É seu principal propósito "levar o Estado do Paraná a ter um índice de no mínimo $20 \%$ da cobertura florestal através da conjugação dos esforços do Poder Público e da Iniciativa Privada" (art. $2^{\circ}$ do Decreto 387/99). Objetiva ainda o estabelecimento de zonas prioritárias de conservação para a manutenção da diversidade biológica dos biomas paranaenses, a promoção das zonas prioritárias de conservação e remanescentes significativos através de "Corredores da Biodiversidade" e a implementação de ações de recuperação florestal de áreas públicas e particulares.

No que se refere ao ICMS Ecológico, trata-se de um importante instrumento de incentivo à criação e manutenção de áreas especialmente protegidas. Criado pioneiramente no Paraná, através da Lei Complementar 59/91, definiu os percentuais de rateio do ICMS a que os municípios têm direito, considerando-se um critério ambiental. Também criou uma nova atitude da parte do setor privado, levando a um aumento substancial das Reservas Naturais Privadas, como as RPPNs, minimizando a pressão sobre as florestas nativas (FAO, 2004).

\section{Percepção do setor produtivo florestal paranaense}

O setor produtivo florestal paranaense, nos últimos anos, passou a ser bem mais fiscalizado do que estimulado, seja com os plantios de espécies nativas ou exóticas. Diante de tal situação e de acordo com dados da Associação Paranaense de Empresas de Base Florestal (APRE, apud ECOFALANTE, 2005), o setor passou a demandar do governo posturas que pudessem efetivar uma política de desenvolvimento da produção florestal, considerando seu potencial de geração de divisas, que representa o $2^{\circ}$ lugar entre os exportadores do agronegócio paranaense e o $3^{\circ}$ na pauta de exportação estadual, perdendo apenas para o segmento de grãos e para o setor automotivo. Trata-se de uma cobrança institucional que pudesse definir claramente o real papel do estado em termos do estímulo à produção a um setor cuja função social e econômica é bastante relevante. Mais especificamente, a Associação de

FLORESTA, Curitiba, PR, v. 40, n. 4, p. 871-888, out./dez. 2010. 
Engenharia, Arquitetura e Agronomia de Ribeirão Preto (AEAARP, 2005) realça o baixo custo para a geração de emprego no setor florestal: "[...] Considerando-se que a atividade florestal é de utilização intensiva da mão de obra durante todo o ano, evitando o seu uso sazonal, fica evidente a grande contribuição que este setor pode oferecer para ampliar a geração de empregos, fixação do homem no campo e a consequente melhoria da qualidade de vida de grande parcela da população brasileira". Souza (2005) afirma que, "apesar do esforço de contenção do desmatamento, o Estado do Paraná, assim como o Brasil, deverá enfrentar nos próximos anos forte escassez do produto, quando o consumo será superior à capacidade de corte nas áreas reflorestadas".

Quanto aos problemas ambientais, o setor levanta que, a exemplo do Brasil, o estado do Paraná também passou a privilegiar uma legislação ecológica avançada. Relativamente a esse tema, de acordo com Soares Neto (2000), a atenção crescente conferida aos problemas ecológicos nas duas últimas décadas tem conseguido melhorar a maneira como as questões ambientais são tratadas pelos governos e pelos agentes econômicos em todo o mundo, como é o caso, por exemplo, da chamada agenda marrom, envolvendo os instrumentos reguladores (IR), os de comando e controle (CEC) e os econômicos ou de mercado (IM).

Outro fator que também vem preocupando o setor produtivo é o processo burocrático, que se tornou cada vez mais exigente quanto aos aspectos de plantio e manejo florestal, dando pouca ênfase às questões técnicas de aptidão, à potencialidade econômica e de geração de renda aos agricultores e à própria questão social daí advinda.

\section{Pesquisa e extensão florestal}

De acordo com Silva $(2001)^{3}$, são seis as funções típicas de Estado na área florestal: a) efetivar o macroplanejamento da proteção e do uso das florestas (embora o direito de propriedade seja livre no Brasil, a floresta é bem de interesse coletivo); b) administrar as áreas florestais públicas (Parques, Florestas, Reservas Biológicas, Estações Ecológicas, Reservas Extrativistas e Reservas de Desenvolvimento Sustentável, que podem ser federais, estaduais ou municipais); c) prestar assistência à clientela florestal, ou seja, aos proprietários das terras com florestas ou àqueles que com elas trabalham (acesso ao crédito, processamento, armazenagem e escoamento da produção); d) promover o fomento da atividade florestal (criar condições e facilitar os meios para que a atividade florestal seja empreendida, envolvendo desde formação de florestas homogêneas até recuperação de áreas degradadas e recomposição de matas ciliares); e) realizar a pesquisa florestal (valendo-se das universidades e de outras instituições de pesquisa, envolvendo pesquisas de novas espécies potencialmente comerciais, que criam e desenvolvem novos produtos de madeira e preocupam-se com processamento, secagem de madeira e aproveitamento de resíduos florestais); f) monitorar, controlar e fiscalizar a cobertura florestal dos proprietários privados.

De acordo com Campanhola (2006), o atendimento à demanda futura de madeira sem degradar as florestas naturais somente poderá ser conseguido se aumentarmos a eficiência e eficácia da produção, da exploração e da conversão da matéria-prima. Nesse sentido, a pesquisa florestal é um dos caminhos para se enfrentar essa situação. Segundo a EMBRAPA-Florestas (2006), "a obrigatoriedade a que está submetida a propriedade rural através da legislação ambiental, configurada principalmente em Área de Preservação Permanente (APP) e a Reserva Legal (RL), colocam as propriedades rurais em situação de passivo ambiental que necessita ser equacionado". Padilha (2004) alerta sobre o custo de efetivar a regularização da reserva legal no Paraná, afirmando que, no aspecto do valor da terra imobilizada com a Reserva Legal Florestal, verifica-se que a imobilização permanente de $20 \%$ da área total das propriedades rurais deve causar um impacto da ordem de $\mathrm{R} \$ 22,4$ bilhões ao setor agropecuário paranaense. Tudo isso demonstra a importância da pesquisa florestal para encontrar caminhos alternativos e de forma sustentável para que agricultores e governo possam equacionar problemas dessa complexidade.

No que se refere à extensão rural, vale ressaltar que, segundo Olinger (1996), a extensão nasceu como um instrumento de ensino e educação informais, fora dos moldes da escola clássica, precisamente para que os agricultores, donas de casa e jovens rurais tivessem oportunidade de aprender sem prejudicar as lides rurais ou domésticas, cotidianas, ou mesmo abandoná-las. O sujeito de sua ação é o ser humano, e o modo principal é a produção e comercialização das safras, com o mínimo possível de dano ao meio ambiente.

\footnotetext{
3 Também citado por Bom e Lehrer (2005) e, também por ROCHA e SILVA, em "As funções de estado na área florestal: suas interrelações com a constituição federal e com o Programa Nacional de Florestas".
} 
Entretanto, a visão da extensão rural pós-anos 1980 e, mais fortemente, pós-1990 também passa a expressar suas ações com foco mais humanista e ambientalista. Segundo Sepulcri (2005), na busca de seu aperfeiçoamento constante, a EMATER-PR iniciou a década de 1990 desenvolvendo o modelo "Extensão Rural do Paraná: Um Modelo Ambiental" (FIALHO et al., 1992), executado no período 19911995, que veio reforçar as ações ambientais e realimentar a base filosófica do serviço de extensão. Pelo diagnóstico feito para a implantação do Modelo Ambiental, seria necessário implementar três diretrizes para seguir as tendências da agricultura do futuro: "a necessidade da modernização das instituições, a promoção da maior participação do público beneficiário no processo de desenvolvimento e o respeito aos recursos naturais através do desenvolvimento sustentado" (SEPULCRI, 1992).

O modelo desenvolveu ações para atender a essas diretrizes. Sustentava-se em três componentes: organização e conscientização, racionalidade no uso dos recursos naturais e do meio ambiente e modernização do processo produtivo. O público beneficiário deveria participar para que as ações fossem adequadas às suas necessidades e para que estivessem conscientes e "preparados para mais um elo na cadeia do saber, do receber e do progredir" (FIALHO, 1993). A racionalidade dos recursos naturais e do meio ambiente, a convivência racional com este, garantindo a sobrevivência das gerações futuras, são os princípios da sustentabilidade.

Nesse aspecto, releva-se a extensão rural agroecológica, "intervenção planejada para o estabelecimento de estratégias de desenvolvimento rural sustentável com ênfase na participação popular, na agricultura familiar e nos princípios da agroecologia como orientação para a promoção de estilos de agricultura sócio-ambiental e economicamente sustentáveis (CAPORAL; COSTABEBER, 2000).

Em especial, referente à extensão florestal, Schaitza (2006) ressalva que "é fundamental contar com um serviço eficiente de extensão que consiga demonstrar as vantagens de aplicar um modelo de ordenamento florestal que permita gerar rendimentos permanentes no tempo, com uma silvicultura baseada em critérios biológicos". De acordo com Pereira (2005), nos estados em que a administração pública não conta com instituições florestais específicas, as tarefas de responsabilidade do governo na área florestal, que não podem ser cumpridas pela iniciativa privada, vêm sendo exercidas, de forma parcial, pelos órgãos ambientais ou, supletivamente, pelas superintendências do Instituto Brasileiro do Meio Ambiente (IBAMA).

As estratégias metodológicas devem envolver os princípios básicos da extensão, quais sejam, de divulgação, sensibilização, conscientização, mobilização e de assistência técnica. Vale ressaltar as dificuldades de implementação desse tipo de cultivo, isto é, não basta o fomento direto, através da disponibilização de mudas ou de doação de insumos ou equipamentos. Há necessidade de muito mais, ou seja, de assistência técnica especializada em plantações florestais, somada às estratégias de sensibilização ambiental e econômica. Trata-se, portanto, do desenvolvimento de toda a Cadeia Produtiva da Madeira.

\section{MATERIAL E MÉTODOS}

A orientação metodológica na pesquisa bibliográfica baseou-se em aspectos sistêmicos interdisciplinares envolvendo conhecimentos das diversas áreas que constituem o setor florestal dentro da abordagem de sustentabilidade, tanto no que se refere às suas características técnicas (de ordem ecológica, econômica e social), quanto administrativas, enfocando a área da política governamental estadual para o setor.

A pesquisa de campo foi desenvolvida com base em dois enfoques metodológicos que interagem: positivista, procurando estabelecer comparações numéricas ou quantitativas para auxiliar na mensuração das diversas variáveis que interferem na cadeia produtiva florestal (os dados foram obtidos por meio de questionários), e fenomenológico, visto ser o objetivo central desta pesquisa o estudo da percepção dos diversos atores dentro da cadeia produtiva da madeira. Significa valer-se da vivência e experiência de vida dos entrevistados, atendendo aos pressupostos fenomenológicos: "A fenomenologia ressalta a ideia de que o mundo é criado pela consciência, o que implica o reconhecimento da importância do sujeito no processo de construção do conhecimento" (GIL, 1999).

Considerou-se como universo da pesquisa todo o estado do Paraná. Porém, como amostra, selecionou-se a região de Curitiba, tendo em vista sua importância no segmento florestal, representando a primeira mais expressiva região do estado em termos de valor bruto da produção (VBP), juntamente com a tradicional região de Ponta Grossa (SEAB/Deral/DEB, 2005). Vale salientar a evolução do VBP florestal que a 
região de Curitiba experimentou do ano de 1998 até 2005, praticamente dobrando a sua participação, passando de 18\% em 1998 para 34\% em 2005. Além disso, a região de Curitiba foi selecionada dada a facilidade de obtenção dos dados, cuja coleta se deu com técnicos da SEAB, EMATER, IAPAR, CEASA e CODAPAR e com alunos da Faculdade Internacional de Curitiba. Considerando essa região, foram selecionados alguns municípios, cuja economia encontra-se relacionada à atividade florestal, medida pelo VBP na região de Curitiba e cujo extrato fundiário indica uma grande concentração de pequenos agricultores. Considerou-se como pequeno agricultor a mesma classificação estabelecida pelo PRONAF (Programa Nacional de Fortalecimento da Agricultura Familiar do Ministério do Desenvolvimento Agrário - MDA).

Quanto aos atores pesquisados, em função das particularidades do universo pesquisado, utilizouse amostra de conveniência, extraída a partir de técnicos especializados da área florestal, empresas ou organizações não-governamentais e produtores rurais envolvidos com a questão florestal, que satisfaziam as restrições da pesquisa. Para facilitar a compreensão, as características dos atores pesquisados encontram-se classificadas em três níveis (GOV, N-GOV e PROD) assim descritos:

1. Governo (GOV): SEAB (e suas vinculadas: EMATER, IAPAR, CODAPAR, CEASA, CLASPAR); SEMA (e suas vinculadas: IAP e SUDERHSA); outras secretarias do governo (SEPL e SEIM).

2. Não-Governo (N-GOV): empresas madeireiras (indicadas pela APRE); universidades estaduais e federais, com cursos relacionados com a área florestal; professores universitários do curso de Engenharia Florestal da UFPR; colégios agrícolas estaduais; ONGs ligadas à área florestal; cooperativas de produção agrícola; associação de agrônomos; associação de engenheiros florestais; associação de técnicos agrícolas; IBAMA (regionais do Paraná); EMBRAPA-Florestas; APEPA (Associação Paranaense das Empresas de Planejamento Agrícola); AMP (Associação de Municípios do Paraná); deputados estaduais e federais que têm vínculo com a atividade florestal; CREA (regionais do Paraná); técnicos específicos de atuação relevante no setor florestal.

3. Produtores Rurais (PROD): apenas pequenos produtores, classificados no PRONAF, que se localizam na Região Metropolitana de Curitiba, cujas propriedades estejam relacionadas com a atividade florestal (cerca de 2.500 propriedades).

O tamanho mínimo de amostra foi estabelecido para cada classe de universo considerando-se a fórmula aproximada de Barbetta (2002). Estabeleceu-se um nível de significância prefixado de 5\%, o que corresponde a um nível de confiabilidade de $95 \%$ sobre os resultados da pesquisa. Uma vez conhecido o tamanho da amostra, foram enviados cerca de 650 questionários, tendo sido respondidos 254 (cerca de 40\%).

O levantamento dos dados é do tipo survey, descritivo, que, segundo Pinsonneault; Kraemer (1993), permite utilizar instrumentos quali-quantitativos, atendendo à complexidade do objeto em estudo, além de dar conta de questões subjetivas, que não podem ser analisadas tão somente a partir da operacionalização de variáveis quantitativas. Segundo Trivinõs (1987), independentemente do tipo de coleta de informações para obtenção de resultados científicos no campo das ciências humanas e sociais, as informações devem apresentar coerência, consistência, originalidade e objetividade.

Realizou-se pré-teste dos questionários, com o objetivo de revisar e direcionar aspectos da investigação, conforme ressalta Richardson (1999). A versão original do questionário foi aplicada para cinco técnicos do sistema estadual de agricultura, três técnicos da iniciativa privada e três produtores rurais da região de Curitiba. A forma de aplicação foi a direta, por telefone e via e-mail. O pré-teste ocorreu em dezembro de 2004 e janeiro de 2005. A pesquisa ocorreu a partir do mês de março de 2005, estendendo-se até setembro do mesmo ano.

Com relação às questões abertas, procurou-se interpretação, discussão e classificação das mesmas, levando-se em conta o referencial teórico estabelecido, assim como os objetivos pretendidos na pesquisa. Como princípio analítico, foi utilizada a análise de conteúdo, tendo como método o discurso do sujeito coletivo (DSC), de Lefevre (2000). A tabulação de todos os dados dos questionários em planilha eletrônica de Excel ocorreu de acordo com a classificação dos grupos de entrevistados e das questões.

\section{ANÁLISE E DISCUSSÃO DOS RESULTADOS}

\section{Condução da política florestal}

Procurou-se identificar como está sendo conduzida a política florestal produtiva no estado na visão dos grupos pesquisados ou, ainda, levantar como percebem a forma como o governo encontra-se estruturado para apoiar e estimular a produção florestal, ao mesmo tempo em que se procurou identificar 
como e onde gostariam que tais estruturas estivessem alojadas, entendidas como fator fundamental para que o estado possa demonstrar suas intenções políticas e administrativas quanto ao desenvolvimento do setor florestal produtivo. Como forma de reforço à crítica dos grupos pesquisados e também para servir de referência para novas proposições, questionou-se sobre o histórico dos programas florestais estaduais que tiveram êxito nas últimas décadas.

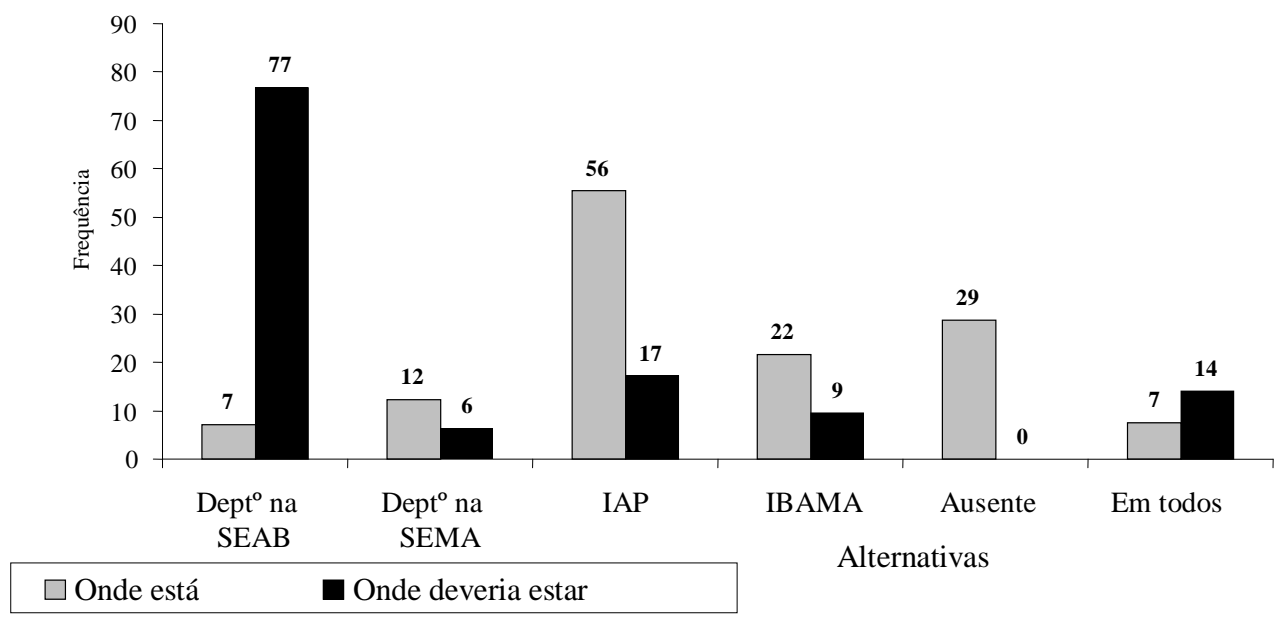

Figura 1. Onde está e onde deveria estar a condução da política de cultivo florestal produtivo do estado, na percepção dos grupos pesquisados.

Figure 1. Where it is and where there should be the driving of the politics of forest productive cultivation of the state, in the perception of the investigated groups.

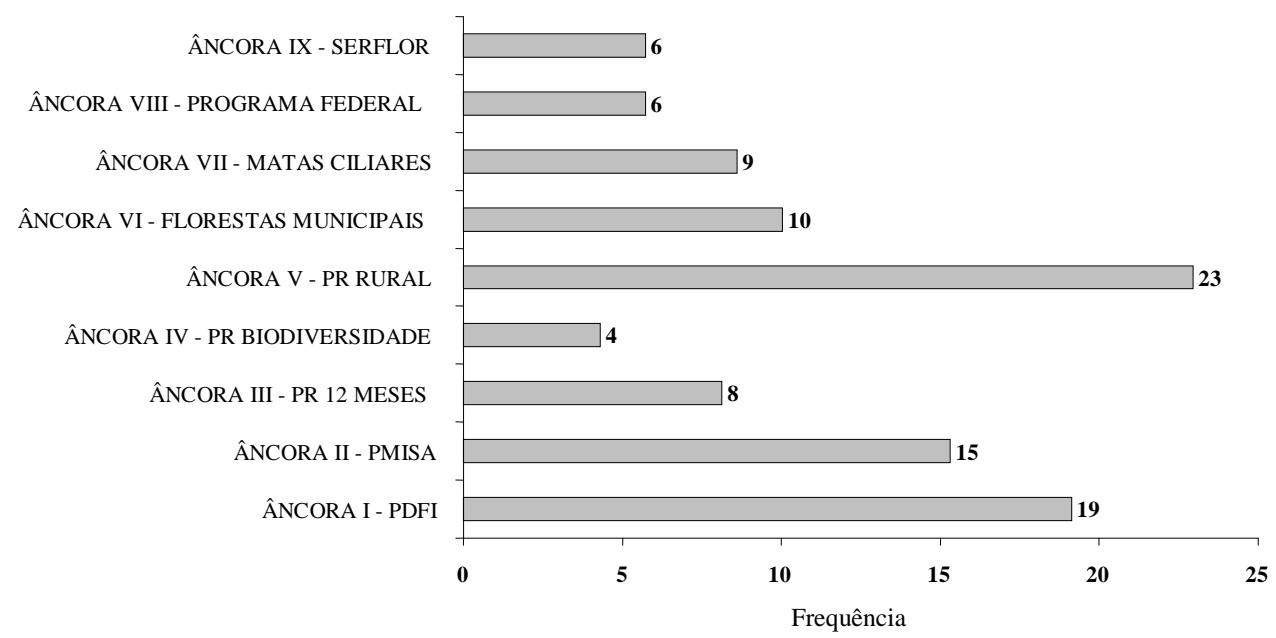

Figura 2. Preferência das âncoras do DSC sobre os programas oficiais de apoio à produção florestal nos últimos 10 anos, na percepção dos grupos pesquisados.

Figure 2. Preference of the anchors of the DSC on the official programs of support to the forest production in the last 10 years, in the perception of the investigated groups.

Assim, pode-se verificar que, de maneira geral (Figura 1), há um reconhecimento de que o governo não se encontra devidamente estruturado e organizado para dar suporte a uma política florestal da forma desejável. Demonstra, assim, a necessidade de se buscar propostas ou políticas públicas que as valorizem, além de possibilitar sua maior inserção no processo produtivo. Nesse sentido, das alternativas relacionadas à condução futura da Política Florestal Produtiva do Estado, a preferência dos grupos pesquisados foi "Em um Departamento da SEAB" (77\%), demonstrando que há uma clara percepção dos 
grupos de que deveria ser a SEAB a conduzir tal política, principalmente por estar afeta à área da produção (a SEAB, no passado, já a havia conduzido).

Buscou-se também levantar a percepção dos grupos com relação a programas florestais que foram implementados nos últimos 10 anos no estado do Paraná. Para tanto, lançou-se mão da metodologia DSC, que foi "ancorada" em nove nomes de programas, que passaram a representar o discurso dos entrevistados (Figura 2).

O amplo conhecimento do Programa Paraná Rural deve-se ao fato de estar associado ao seu estado, desde o final da década de 1980 até meados da década de 1990. Trata-se de um programa de reconhecimento mundial, tendo sido recomendado, por parte do Banco Mundial (BIRD), a outros países do mundo, como modelo de desenvolvimento rural sustentável. De acordo com Muzilli (2005), em verdade, as preocupações com a conservação do solo no Paraná tiveram início na década de 1970, com os estudos desenvolvidos através do Projeto Noroeste e as experiências práticas realizadas por meio do Programa Integrado de Conservação do Solo (PROICS), que operou entre 1975 e 1980, e do Programa de Manejo Integrado de Solos e Águas (PMISA), entre 1984 e 1998). A partir do conhecimento acumulado através dessas iniciativas, foi implementado o Programa de Manejo das Águas, Conservação do Solo e Controle da Poluição em Microbacias Hidrográficas, conhecido como Paraná Rural, entre 1989 e 1997. Vale ressaltar que a base desse programa foi o planejamento e a implementação das ações conservacionistas e produtivas em microbacias hidrográficas. Essas unidades geográficas, devido à dinâmica das águas que a caracterizam, constituem um espaço territorial adequado para o desenvolvimento de trabalhos voltados para a gestão ambiental. Especificamente, pode-se verificar pela avaliação do Programa Paraná Rural, realizada pelo IPARDES, que os produtores realmente conheciam muito bem esse programa: "Pode-se constatar que, de um modo geral, os produtores conhecem o Programa Paraná Rural. Em 90\% das microbacias, mais de 60\% dos produtores conhecem o programa" (IPARDES, 1993). O segundo programa mais conhecido foi o PDFI (Programa de Desenvolvimento Florestal Integrado). Trata-se de um programa que também teve início no final da década de 1980 e tinha como objetivo o estabelecimento de instrumentos de fomento ao desenvolvimento florestal. Em especial, visava incentivar o uso dos recursos florestais através de processos tecnológicos apropriados e capazes de minimizar impactos em ecossistemas, tudo isso direcionado para a busca da sustentabilidade dos empreendimentos florestais. Ficou conhecido por estimular os trabalhos em parcerias entre o estado, os municípios e as empresas ligadas ao setor florestal. Além disso, sobressaiu com os trabalhos de produção de mudas e de recomposição das matas ciliares. O terceiro programa que mereceu destaque foi o PMISA (Programa de Manejo Integrado de Solos e Águas), desenvolvido no período de 1983 a 1985, tendo sido estruturado e implementado em microbacias hidrográficas. Um dos componentes do PMISA era o reflorestamento de matas ciliares com fins de conservação, além do plantio de florestas produtivas com fins econômicos nas propriedades rurais. Esses plantios eram associados a outras práticas agrícolas e de conservação de solos. Foi a base que deu sustentação à formulação do PR RURAL e ao próprio PDFI.

\section{Sugestões para a expansão da base florestal produtiva}

Pretendeu-se, no caso, captar as sugestões dos grupos para a expansão da base florestal produtiva paranaense no que se refere ao fomento da atividade florestal, à integração das PPRs à CPM, à estrutura administrativa, bem como à pesquisa e extensão florestal. Tudo isso de forma sustentável.

Vale ressaltar, entretanto, algumas premissas que permeiam a discussão a respeito da sustentabilidade das plantações florestais e que, certamente, servem como contribuição para a formulação das sugestões apontadas pelos grupos pesquisados. Assim, a opção por uma estratégia que conduza a esse tipo de mudança (ou adaptação) no setor florestal irá requerer, por parte das instituições envolvidas na CPM, o estabelecimento de uma visão holística da sustentabilidade das plantações florestais (ecologicamente adequado, socialmente justo e economicamente viável), tanto do ponto de vista do governo quanto das empresas e produtores. Esse enfoque de "sustentabilidade" não é, de todo, tão desconhecido assim, pois o próprio histórico do setor florestal já indicava tais tendências. De acordo com FAO (2005, apud ABRAF, 2006), o reflorestamento cobre uma área de 5,2 milhões de hectares no Brasil e é, sem dúvida, um dos principais segmentos da economia brasileira geradores de emprego, oferecendo uma significativa contribuição socioeconômica para o país, o que, sem dúvida, pode proporcionar a fixação do homem no campo, revertendo o quadro da pressão social aos grandes centros urbanos. Além disso, a indústria de madeira processada mecanicamente exerce uma importante influência na balança 
comercial brasileira, causando um forte impacto na geração de renda, impostos e divisas. Quanto à questão meramente ecológica, o setor também está bastante preocupado, procurando desenvolver sistemas de produção que minimizem o impacto causado ao meio ambiente. Como base para essa discussão, encontra-se o próprio conceito de Manejo Florestal Sustentável de Uso Múltiplo, que implica a administração do recurso natural para a obtenção de benefícios econômicos, sociais e ambientais respeitando os mecanismos de sustentação do ecossistema objeto do manejo e considerando cumulativa ou alternativamente a utilização de diversas espécies madeireiras, de múltiplos produtos e subprodutos não-madeireiros, bem como a utilização de outros bens e serviços de natureza florestal.

Entretanto essa "sustentabilidade", embora possa ser motivo de exemplo em algumas situações, ainda está longe de ser atingida de forma global, motivo pelo qual se buscaram algumas sugestões sob a perspectiva dos grupos selecionados. Para tanto, foi utilizada a metodologia DSC, "ancorada" em algumas frases que passaram a representar o discurso dos entrevistados.

$\mathrm{O}$ grupo de sugestões apontadas encontra-se, de certa forma, relacionado às dificuldades enfrentadas, ou seja, elas se complementam. Significa, portanto, que, ao sugerir, os entrevistados buscam a compensação das dificuldades que vêm sentindo ao longo do tempo. Assim, ao se compararem os grupos de dificuldades e de sugestões, verifica-se que as quatro âncoras que mais se destacaram no quadro de dificuldades se repetem no quadro de sugestões, variando apenas o grau em que foram classificadas (Tabela 1).

Tabela 1. Comparativo entre os indicativos de dificuldades e de sugestões quanto à expansão da base florestal produtiva paranaense, na percepção dos grupos pesquisados (GOV, N-GOV, PROD ordem de importância).

Table 1. Comparatively between the indicative ones of difficulties and of suggestions as for the expansion of the forest productive base from Paraná, in the perception of the investigated groups (GOV, N-GOV, PROD - order of importance).

\begin{tabular}{llll}
\hline \multicolumn{2}{l}{ As quatro maiores dificuldades apontadas } & As quatro maiores sugestões apontadas \\
\hline $1^{\text {a }}$ & Faltam informações técnicas e de mercado & $1^{\text {a }}$ & Desenvolvimento de política florestal \\
$2^{\text {a }}$ & Excesso de burocracia & $2^{\text {a }}$ & Simplificação burocrática \\
$3^{\text {a }}$ & Falta apoio governamental & $3^{\text {a }}$ & Assistência técnica e extensão florestal \\
$4^{\text {a }}$ & Pouca assistência técnica aos produtores & $4^{\text {a }}$ & Informações fidedignas aos produtores \\
\hline
\end{tabular}

Ainda dentro da questão da política florestal, procurou-se identificar algumas sugestões dos grupos pesquisados de como a atividade silvicultural pode contribuir dentro da equação de produção das PPRs para que as mesmas possam ter maior participação na CPM. Trata-se de analisar a visão estratégica (de longo prazo) que os diversos atores têm a respeito da propriedade rural e de como o plantio florestal pode contribuir para o sucesso desse propósito. Em outras palavras, qual seria o papel do plantio florestal na composição das forças produtivas da pequena propriedade. Depreende-se de tudo isso que, no seu conjunto, a preferência dos grupos pesquisados encontra-se definida pela maior organização dos agricultores em grupos ou associações, bem como na sua maior capacitação técnica. Essa constatação também pode ser observada pelo BNDES (2006, apud BELING et al., 2006), quando afirma que a elevação da agregação de valor da produção está relacionada à promoção da capacitação e especialização da mão de obra utilizada tanto pelos agricultores como pela indústria de base.

Buscou-se ainda a coleta de sugestões quanto à pesquisa florestal no estado. A análise dessa percepção também teve por base a metodologia DSC, que foi "ancorada" em nove sugestões. As sugestões que mais se destacaram foram, em ordem de preferência: "Diversificar a pesquisa Florestal" (21\%); "Pesquisa nas PPRs" (17\%); e "Pesquisa em manejo sustentável" (14\%). Falta ainda no estado o desenvolvimento de pesquisa básica em florestas, como também a respeito da qualidade de produtos tendo a madeira como matéria-prima. Além disso, há bastante pulverização dos esforços, dificultando toda e qualquer articulação e comunicação para a promoção desse tipo de pesquisa. Não bastasse isso, faltam também incentivos ao setor florestal e políticas de longo prazo para a pesquisa. Isso se reflete como entraves práticos ao longo da cadeia da madeira, sendo os mais relevantes os problemas de transferência de tecnologia para o pequeno produtor, questionamentos ambientais sobre espécies exóticas e restrições e exigências legais sem fundamentação científica, além da falta de dados técnicos na área de manejo sustentável das plantações florestais. Além disso, há que se ressaltar a tradicional distância entre o

FLORESTA, Curitiba, PR, v. 40, n. 4, p. 871-888, out./dez. 2010. 
que há de produção científica e o que se consegue divulgar, isto é, há muita pesquisa pronta que não chega aos produtores. Foi a partir desse quadro não satisfatório que os entrevistados se viram questionados. Provavelmente seja essa a explicação pelo maior índice de sugestões ter recaído sobre "Diversificar a pesquisa florestal", ou seja, a busca da pesquisa básica, seja no âmbito privado ou governamental. Há clara evidência de que faltam dados tecnológicos desde o plantio até o produto final, sem contar com os aspectos de custo, retorno do investimento, segurança na colheita e sustentabilidade, entre outros. A segunda sugestão refere-se à Pesquisa nas PPRs. Torna-se relevante assinalar que há pesquisa, tanto de manejo quanto de sistemas de produção florestal, adaptada aos cultivos empresariais, mas ainda pouco se observa para pequenas áreas. No que se refere ao processo de verticalização, também muito poucos casos são verificados no estado, necessitando-se estudar melhor as diversas alternativas de parcerias, de integração ou de cooperação, em que as PPRs pudessem produzir de forma escalonada, padronizada e com possibilidade de comercialização assegurada. A terceira sugestão refere-se à "Pesquisa em manejo sustentável". Trata-se de uma área muito discursada, mas ainda com poucos resultados práticos ou de pesquisa. Ocorre que, tendo em vista a internalização da variável ambiental em, praticamente, todas as áreas da produção rural, as análises econômicas devem passar a levar em conta a busca de padrões de desenvolvimento sustentável em suas variáveis ecológicas, econômicas e sociais. Assim, devem enfocar custos de proteção ambiental, assim como análise de mercado, formas de comercialização interna e externa, produtos diferenciados e suas cadeias produtivas.

Também foram solicitadas aos grupos pesquisados sugestões quanto ao papel da extensão florestal no estado. A análise dessa percepção também teve por base a metodologia DSC, "ancorada" em seis sugestões para a extensão florestal, que passaram a representar o discurso dos entrevistados. As três sugestões que mais se destacaram foram (Figura 3): "Contratação e capacitação de técnicos" (32\%), "Assistência e extensão florestal às PPRs" (20\%) e "Criar programa de extensão florestal" (17\%).

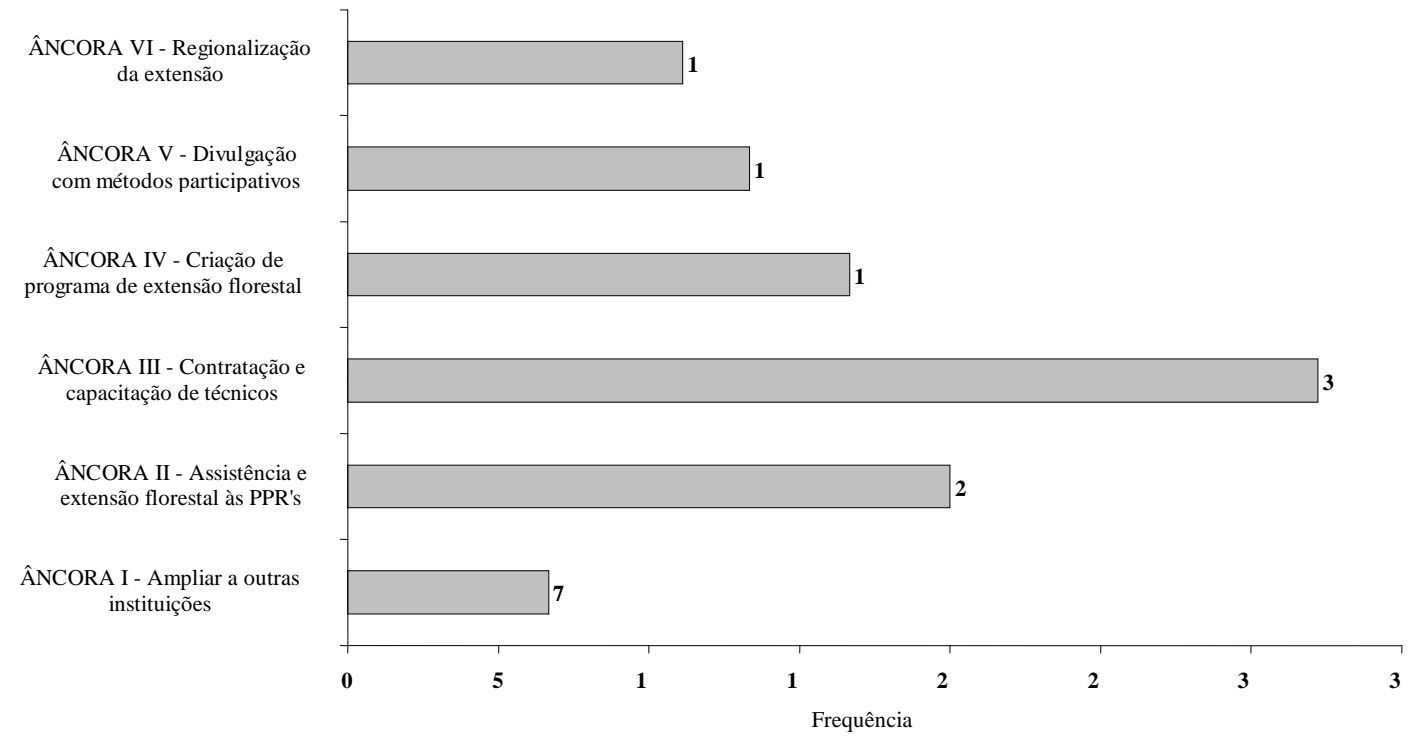

Figura 3. Expectativa quanto à extensão florestal, na percepção dos grupos pesquisados.

Figure 3. Expectation as for the forest extension, in the perception of the investigated.

O discurso da extensão florestal é bastante polêmico, dada a própria "extensão" do conceito de extensão rural, cujos debates se concentram entre concepções e práticas contraditórias que, dependendo da forma e intensidade, poderão redundar na dependência ou na autonomia dos agricultores, notadamente os pequenos, cuja educação formal é limitada e de fácil influência. Assim, ressaltam-se as observações de Veiga, 1997 (apud MALINOVSKI, 2002): "O atual sistema governamental de extensão rural teria poucas condições de resgatar as perdas causadas pelo sistema de agricultura familiar". Segundo o IBAMA (apud MALINOVSKI, 2002), não há extensão florestal no Brasil, a não ser "ações pontuais, desenvolvidas por iniciativa de alguns órgãos florestais estaduais, principalmente na região Sudeste e Sul, onde, a partir dos 
anos 1970, iniciou-se uma experiência de introdução da silvicultura em pequenas e médias propriedades rurais". O modelo de extensão escolhido e a falta de preparo dos extensionistas nas questões florestais agrava as falhas da extensão florestal no Brasil.

No entanto, o que se busca caracterizar em um trabalho de extensão rural é a sua vertente mais pedagógica, baseada em preceitos da construção da cidadania e a consequente autonomia do agricultor, seja na esfera econômica, política, técnica ou sociocultural. Nesse contexto, a extensão adquire o seu compromisso com o desenvolvimento rural de forma integral e não somente o agrícola, pelas tecnologias específicas de aumento da produtividade da terra, como reza o conceito oposto. Na perspectiva teórica desse contexto, poderia até ser evocados os teóricos da área, como a concepção de autonomia fundada em uma relação dialógica, defendida por Paulo Freire (1982) em seu ensaio "Extensão ou Comunicação", de 1969. Nesse estudo, o autor apresenta uma discussão a respeito do papel dos extensionistas rurais como educadores e considera o processo de extensão como uma atividade educativa. Assim, educadores e educandos assumiriam o papel de "sujeitos cognoscentes", mediatizados pelo objeto que desejam (ambos) conhecer. Não há "ensinadores", nem "ensinantes", mas, ao contrário, dois agentes "aprendizes". Nesse sentido, como um professor, o extensionista também deve fazer uso da comunicação, se é que sua intenção é atingir ao homem e sua cultura (FREIRE, 1982). Essa foi a proposta de Paulo Freire para transformar o serviço de extensão rural, de uma simples transferência tecnológica, em um processo de educação/comunicação, dialógico e comprometido com o seu desenvolvimento. A extensão deixava, assim, de ser um instrumento de dominação ou de invasão cultural, para ser um mecanismo pelo qual o agricultor poderia alcançar a sua independência e, mais do que isso, de sua liberdade. Isso significa que é possível buscar o desenvolvimento rural através da atividade florestal e da promoção do uso sustentável dos recursos florestais e da terra, como é o caso de restauração de áreas de preservação permanente (APP) e recomposição de RL, com favorecimento especial aos produtores do extrato de renda mais baixo. Entretanto a administração e o uso racional do recurso florestal dependem diretamente de quem o explora, cabendo à extensão florestal o papel de transferir essa "responsabilidade compartilhada". Portanto, rever o modelo de gestão e referencial teórico de assistência técnica e extensão rural passa a ser fundamental para a implementação de um serviço voltado para a agricultura familiar, em bases sustentáveis, em parceria com organizações sociais.

Por coincidência, as sugestões dos grupos se concentraram nos três grandes desafios da exten são florestal: programa de ação, contratação e capacitação, e assistência às PPRs. No caso, a "Contratação e capacitação de técnicos" foi a sugestão mais expressiva, ou seja, um reconhecimento de que tanto técnicos quando produtores necessitam ser melhor capacitados para realizarem investimentos de prazos longos. Constata-se, ainda, que há poucos técnicos atuando na área florestal, principalmente nos órgãos oficiais de extensão. A segunda sugestão foi "Assistência e extensão florestal às PPRs", ou seja, trata-se da busca de se garantir apoio qualitativo aos agricultores mais carentes, cujos investimentos necessitam de estímulo e assistência para se consolidarem. Ao mesmo tempo, o enfoque recai não apenas na oferta tecnológica, com a respectiva assistência, mas, sobretudo, no serviço de extensão, como forma de promoção da autonomia do agricultor, notadamente o pequeno. A terceira sugestão, "Criar programa de extensão florestal", retrata uma área muito mencionada, principalmente em palcos políticos, mas ainda com poucos resultados práticos. Ocorre que tanto a iniciativa privada quanto os órgãos governamentais carecem de propostas mais audaciosas e com ingredientes técnicos consistentes. Não basta, porém, apenas dispor de técnicos capacitados se não houver um programa comprometido com os desafios da extensão.

Como complemento, também foi solicitado aos grupos como deveria ser constituído o corpo técnico para dar suporte à expansão da base florestal produtiva paranaense. A análise dessa percepção também teve por base a metodologia DSC, "ancorada" em frases que passaram a representar o discurso dos entrevistados. Assim, pode-se observar que a maior preferência recaiu sobre "Ter 1 técnico por região do estado" (37\%), isto é, 20 técnicos no total. A seguir, surge a proposta de "Criação de um órgão específico", com índice de $26 \%$. Em verdade, trata-se de uma proposta radical, comparada com a realidade atual da estrutura estadual: a SEAB, por exemplo, não dispõe sequer de um profissional com formação florestal específica dentro de seu corpo técnico, e a A EMATER, responsável pela extensão, também tem um quadro irrisório desses profissionais. A segunda proposta também é bastante radical e representa uma velha reivindicação do setor florestal no estado, ou seja, trata-se da criação de uma estrutura específica no governo para atender ao setor. Em verdade, o setor florestal carece, realmente, de uma instituição governamental voltada, exclusivamente, para a produção, para o desenvolvimento de toda

FLORESTA, Curitiba, PR, v. 40, n. 4, p. 871-888, out./dez. 2010. 
a cadeia produtiva e para a implementação dos grandes projetos comprovadamente sustentáveis. Pela representatividade econômica, social e até mesmo ecológica do setor florestal, há necessidade de ele constar na pauta das prioridades estaduais. É isso o que o setor reivindica há tempos. Essa nova instituição deveria dispor de autonomia administrativa suficiente para coordenar as ações de desenvolvimento florestal de toda cadeia produtiva, além de formular políticas e implementar programas para o desenvolvimento do setor florestal, envolvendo financiamento, sistema de informação, fomento, desenvolvimento científico e tecnológico, assistência técnica, extensão florestal, capacitação, educação ambiental, verticalização da produção, pesquisa florestal, constituição de fundo específico e reestruturação de pessoal, entre outras ações.

\section{Certificação florestal}

Essa questão pretendeu identificar os conceitos que os grupos pesquisados têm em relação à Certificação Florestal, um novo instrumento tecnológico que vem sendo estimulado em todo o mundo, principalmente para atender aos aspectos ecológicos, econômicos, sociais e administrativos. Entretanto, no nível das PPRs, são muitas as dúvidas a respeito desse tema. Daí a importância de se levantar a relevância que a certificação tem quando aplicada às plantações florestais, de forma a obter sugestões a serem consideradas em futuros programas florestais. De acordo com o INMETRO (2006), internacionalmente, a certificação florestal voluntária vem se desenvolvendo desde a década de 1980 , contando com vários sistemas operando e competindo entre si. No Brasil, desde 1996, a Sociedade Brasileira de Silvicultura (SBS), em parceria com algumas associações do setor, instituições de ensino e pesquisa, organizações não-governamentais e com apoio de alguns órgãos do governo, vem trabalhando com um programa voluntário denominado CERFLOR - Programa Brasileiro de Certificação Florestal. Porém, segundo Amaral Neto; Carneiro (2006), quanto à participação do movimento social no processo de certificação, é preciso ocupar os espaços existentes e envolver mais os atores direta e indiretamente afetados no processo. Para tanto, torna-se necessário fortalecer a Câmara Social do FSC/Brasil, para exigir mecanismos que garantam a participação de todos os envolvidos. Nesse sentido, de acordo com o Relatório de Atividades do FSC-Brasil-2004 (FSC, 2005), em 2002 o FSC Internacional iniciou as discussões para criação de uma política que pudesse facilitar o acesso à certificação para operações florestais com manejo em pequena escala e baixa intensidade (SLIMF, do inglês Small and Low Intensity Managed Forests).

Quanto à percepção dos grupos, pode-se depreender que, em geral, concordam com o fato de que a certificação "Facilita o comércio de madeira e produtos florestais" (54\%), além de se "Pautar em princípios sociais, econômicos e ambientais" (22\%) e "Assegurar qualidade e preço dos produtos florestais" (44\%).

\section{CONSIDERAÇÕES FINAIS}

Tendo por base as percepções dos atores pesquisados (Gov; N-Gov e Prod), conclui-se que há um forte interesse, por parte dos atores florestais pesquisados, em que o setor florestal produtivo do estado fosse representado pela Secretaria de Agricultura e do Abastecimento, uma vez que se trata do órgão governamental responsável pela produção no meio rural, isto é, assim como a SEAB desenvolve as políticas de grãos e de criações, também deveria desenvolver a política das plantações florestais produtivas. Essa constatação serve para confirmar a terceira hipótese lançada na pesquisa, cuja premissa era a de que a política florestal produtiva poderia se adequar melhor ao processo de inclusão das PPRs na cadeia produtiva da madeira caso o modelo administrativo que a gerencia fosse transferido das estruturas da SEMA para as da SEAB. Decorrente desse interesse de mudança da política florestal produtiva, pôdese verificar ainda que:

- Sob a coordenação da SEAB, desde que devidamente estruturada em termos tecnológicos e de pessoal habilitado, as PPRs poderiam receber apoio mais efetivo, principalmente para se organizarem em grupos ou associações, bem como para capacitação, condições mínimas necessárias para poderem se integrar mais competitivamente na CPM, agregando valor à sua produção;

- A SEAB, com suas vinculadas, encontra-se em melhores condições de implementação da integração das PPRs aos sistemas de certificação florestal, por se tratar de instrumento que facilita o acesso ao mercado dos produtos florestais; 
- Os esforços da pesquisa florestal no estado, cuja estrutura encontra-se vinculada à SEAB, serão direcionados para a diversificação das atividades produtivas, incluindo as PPRs em suas linhas de pesquisa;

- A atividade de extensão rural oficial poderia passar a contar, em seu quadro funcional, com técnicos capacitados para orientar as ações de extensão voltadas às atividades florestais;

- A SEAB poderia compor um corpo técnico mínimo capaz de atender aos produtores de acordo com as suas regiões administrativas;

- Por tudo isso, a estrutura administrativa para a condução da política de plantações florestais no estado deveria ser conduzida pela SEAB.

\section{REFERÊNCIAS}

AHRENS, S. O "novo" Código Florestal Brasileiro: conceitos jurídicos fundamentais. Trabalho voluntário apresentado no VIII Congresso Florestal Brasileiro. São Paulo: Sociedade Brasileira de Silvicultura. 2003. 15 p.

AICHER, C. A política florestal europeia: um sonho ou uma realidade? Ciência Florestal, Santa Maria, v. 14, n. 2, p. 177-188, 2004. Disponível em: <http://www.ufsm.br/cienciaflorestal/artigos/v14n2 /A17V14N2.pdf>. Acesso em 25 ago. 2005.

AMARAL NETO, M.; CARNEIRO, M. Certificação florestal: como aumentar a participação dos movimentos sociais e diminuir os impactos às comunidades. Disponível em:<http://www.iieb.org.br /arquivos/artigo_certificacao_florestal.pdf>. Acesso em 10 ago. 2006.

ASSOCIAÇÃO DE ENGENHARIA, ARQUITETURA E AGRONOMIA DE RIBEIRÃO PRETO (AEAARP0). Florestas de produção: atividade geradora de empregos, renda e exportação. Diretrizes Estratégicas. Carta de encaminhamento. Disponível em: 〈http://sites.netsite.com.br/aeaarp/carta.htm〉. Acesso em 25 ago. 2005.

ASSOCIAÇÃO PARANAENSE DE EMPRESAS DE BASE FLORESTAL (APRE). Correspondência ao Secretário de Estado do Meio Ambiente e Recursos Hídricos do Paraná. (Protocolo SEMA $\mathrm{n}^{\circ}$ 8.518.420-2 em 01/7/05), 30 de junho de 2005.

BARBETTA, P. A. Estatística aplicada às Ciências Sociais. 5. ed. Cap. 3. Florianópolis: UFSC, 2002.

BELING, R. R. (Org.). Anuário brasileiro da silvicultura. Santa Cruz do Sul (RS): Santa Cruz, 2006.

BOM, R.; LEHER, A. O Estado e o setor florestal. Disponível em: >http://www.celuloseonline.com.br/ colunista/colunista.asp?IDAssuntoMateria=204\&iditem>Acesso em 25 dez. 2005.

BRASIL. Secretaria de Formulação de Política e Normas Ambientais (SFP). Diretrizes para utilização de recursos florestais. Disponível em: <http://www.ipef.br/legislacao/diretrizes.asp >. Acesso em 23 set. 2005.

Ministério do Meio Ambiente, dos Recursos Hídricos e da Amazônia Legal (MMA). Diretrizes para a política de conservação e desenvolvimento sustentável da Mata Atlântica. Brasília-DF, 1998. Disponível em: 〈http://www.ipef.br/legislacao/diretrizmataatlantica.pdf>. Acesso em 25 ago. 2006.

CAMPANHOLA, C. A pesquisa florestal brasileira. Disponível em: <http://www.ambientebrasil.com. $\mathrm{br} /$ composer.php3?base=./florestal/index.html\&conteudo=./florestal/artigos/pesq_florest.html $>$. Acesso em 23 nov. 2006.

CHIAVENATO, I. Teoria geral da administração: abordagens descritivas e explicativas. 4. ed. São Paulo: Makron Books, 1993.

CAPORAL, F. R.; COSTABEBER, J. A. Agroecologia e desenvolvimento rural sustentável: perspectivas para uma nova extensão rural. Agroecologia e Desenvolvimento Rural Sustentável, Porto Alegre, v. 1, n. 1, pág. 16-37, jan./mar. 2000.

ECOFALANTE. Jornal ambiental. Falta de vistoria paralisa atividade florestal no Paraná. Disponível em: <http://ecofalante.terra.com.br/sub/noticias.php?set=369>. Acesso em 18 abr. 2005.

FLORESTA, Curitiba, PR, v. 40, n. 4, p. 871-888, out./dez. 2010. 
EMPRESA BRASILEIRA DE PESQUISA AGROPECUÁRIA (EMBRAPA). Adequação ambiental de sistemas de produção no Paraná. Disponível em: <http://www.cnpf.embrapa.br/pesquisa /macro4porfirio/>. Acesso em 20 nov. 2006.

Embrapa 32 anos estimulando o crescimento do Brasil: a nova agricultura tropical. Disponível em: http://www21.sede.embrapa.br/a_embrapa/unidades_centrais/acs/eventos/embrapa32anos/index _html/mostra_documento. Acesso em 25 jul. 2005.

FERREIRA, I. S. Tutela Penal do Patrimônio Cultural. São Paulo: RT, 1995. 126 p.

FIALHO, J. T. Produzir sem destruir: questão de decisão. Curitiba, 1993. 338 p.

FIALHO, J. T.; SANTOS, L. M. F. dos; TRENTO, E. J. Extensão rural do Paraná: um modelo ambiental. Curitiba: EMATER, 1992. 36 p.

FOOD AND AGRICULTURE ORGANIZATION OF THE UNITED NATIONS (FAO). Valoración de los bosques: contexto, problemas y directrices. Roma, 1997. 69 p.

Incentivos e mecanismos financeiros para o manejo florestal sustentável na região Sul do Brasil. Relatório: MENDES, Jefferson B. R03_FAO_01_MECANISMOS_FINANCEIROS. Curitiba, 6 fev. 2004.

FOREST STEWARDSHIP COUNCIL (FSC). Relatório de Atividades 2004 - Brasil. Disponível em: <http://www.fsc.org.br/arquivos/relatorio\%20de\%20atividades\%20FSC\%202004.doc>. Acesso em 25 jul. 2005.

FREIRE, P. Extensão ou comunicação. Rio de Janeiro: Paz e Terra, 1982.

GIL, A. C. Métodos e técnicas de pesquisa social. São Paulo: Atlas, 1999.

GRIPP, D. O. Levantamento dos instrumentos de política florestal do estado do Rio de Janeiro. Universidade Federal Rural do Rio de Janeiro. Instituto de Florestas. Departamento de Silvicultura. Disponível em <http://www.if.ufrrj.br/inst/monografia/Monografia\%20Debora\%20Oliveira.pdf>. Acesso em 8 set. 2006.

GRON, A. H. The Economic Foundations of Forest Politics. Unasylva - Vol. 1, n. 3. Food and Agriculture Organization of the United Nations. Disponível em: <http://www.fao.org/docrep/x5341e /x5341e00.htm>. Acesso em 8 set. 2006.

INSTITUTO AMBIENTAL DO PARANÁ (IAP). Desenvolvimento florestal. Página oficial do IAP. Informações Gerais. Disponível em <http://www.pr.gov.br/meioambiente/iap/>. Acesso em 12 jan. 2006.

LEFEVRE, F; LEFEVRE, A. M. C. O discurso do sujeito coletivo. Um novo enfoque em pesquisa qualitativa. (Desdobramentos). Caxias do Sul: EDUCS, 2003.

MALINOVSKI, R. A. Reflorestamento em áreas limítrofes de propriedades rurais em São José dos Pinhais (PR): análise de percepção e de viabilidade econômica. 96 f. (Dissertação em Ciências Florestais) - Universidade Federal do Paraná, Curitiba, 2002.

MUZILLI, O. Degradação e recuperação do solo sob uso agrícola - o caso do Estado do Paraná. Disponível: <http://www.cemac-ufla.com.br/trabalhospdf/Palestras/Palestra\%20Osmar\%20Muzilli.pdf>. Acesso em 23 set 2005.

OLINGER, G. Ascensão e decadência da extensão rural no Brasil. Florianópolis: EPAGRI, 1996.

PEREIRA, H. dos S. Estado actual de la informacion sobre instituciones forestales. FAO, 2005. Disponível em: <http://www.fao.org/DOCREP/006/AD399S/AD399s06.htm>. Acesso em 04 ago. 2005.

PIERANGELLI, J. H. Códigos penais do Brasil: evolução histórica. Compilação. Bauru: Ed. Jalovi. 1980.

ROCHA, J. das D. de S.; SILVA, J. de A. As funções de estado na área florestal: suas inter-relações com a Constituição federal e com o Programa Nacional de Florestas. Revista Floresta. Curitiba, PR, v. 39, n. 
2, p. 253-271, abr./jun. 2009. Disponível em: <http://ojs.c3sl.ufpr.br/ojs2/index.php/floresta/article/view File/14554/9776>. Acesso em 10 out. 2009.

SALES, M. Lei de crimes ambientais. Jus Navigandi, Teresina, ano 2, n. 24, abr. 1998. Disponível em: <http://jus2.uol.com.br/doutrina/texto.asp?id=1706>. Acesso em 10 dez. 2006.

SANTOS, A. J. dos. Subsídios para a formulação de uma política florestal regionalizada no estado do Paraná. Análise Conjuntural, Curitiba, v. 16, n. 1-2, p. 6-10, jan./fev., 1994.

SEPULCRI, O. Estratégias e trajetórias institucionais da empresa de assistência técnica e extensão rural do Paraná (EMATER-PR). Dissertação (Mestrado em Desenvolvimento Econômico) - Setor de Ciências Sociais Aplicadas - Universidade Federal do Paraná, Curitiba, 2005.

SILVA, J. A. As funções de estado na área florestal. Revista Floresta e Ambiente. V. 8, n. 1, p. 223-226, jan./dez. 2001. Disponível em: <http://www.if.ufrrj.br/revista/pdf/Vol8\%20223A226.pdf>. Acesso em 10 dez. 2006.

SOARES NETO, C. L. A regulamentação ambiental: instrumentos e implementação. Monografia (Direito) - PUC-PR, 2000, Curitiba, 2000.

SOUZA, N. A. de. Arranjos produtivos locais: o caso de chapas e laminados. Dissertação (Mestrado em Desenvolvimento Econômico) - Setor de Ciências Sociais Aplicadas, Universidade Federal do Paraná, Curitiba, 2005.

SCHAITZA, E. Uma nova postura em relação à Reserva Legal. Curitiba, 2006. Trabalho não publicado.

TOURINHO, L. A. M. O Código Florestal na pequena propriedade rural: um estudo de caso em três propriedades na microbacia do Rio Miringuava. 95 f. Dissertação (Mestrado em Geografia) - Setor de Ciências da Terra, Universidade Federal do Paraná, Curitiba, 2005. 
